\title{
Role of Endothelins and Nitric Oxide in the Pulmonary Circulation of Perinatal Lambs During Hyperoxia and Hypoxia
}

\author{
DOMINIQUE BIARENT, IVES HUBLOUE, GILBERT BEJJANI, CHRISTIAN MÉLOT, PASCALE JESPERS, ROBERT NAEIJE, \\ AND MARC LEEMAN
}

\author{
Laboratory of Physiology, Faculty of Medicine, Erasme Campus of the Free University of Brussels, B-1070 Brussels, Belgium
}

\begin{abstract}
Endothelins (ET) have opposite vascular effects mediated through different receptors: $\mathrm{ET}_{\mathrm{A}}$ receptors mediating vasoconstriction and $\mathrm{ET}_{\mathrm{B}}$ receptors mediating vasoconstriction as well as vasodilation. The role of ET in acute hypoxic pulmonary vasoconstriction (HPV) was studied after dual ET receptor blockade with bosentan and nitric oxide (NO) synthase inhibition with nitro-Larginine (L-NA). We started from the hypothesis that ET antagonism may inhibit HPV but, if not, would do so after NO synthase inhibition. HPV was evaluated in anesthetized lambs, with an intact pulmonary circulation, by the increase in the mean pulmonary artery pressure (Ppa) minus occluded Ppa (Ppao) gradient in response to hypoxia (inspiratory oxygen fraction of 0.1 ) at different levels of pulmonary flow (multipoint pressure/flow relationships). ET receptor antagonism decreased pulmonary and systemic vascular tone both in hyperoxia and hypoxia. ET antagonism had no effect on HPV. NO synthase inhibition increased pulmonary vascular tone more in hypoxia than in hyperoxia so that HPV was enhanced. After L-NA, bosentan still decreased pulmonary vascular tone in hypoxia but did not affect the magnitude of HPV. The present results suggest that ET and NO are involved in the regulation of basal pulmonary vascular tone. Furthermore, the vasodilator effect of bosentan persisted in the presence of NO synthase inhibition, suggesting a non NO-dependent vasodilator mechanism. The results from these experiments are in agreement with the idea that ET do not play a major role in HPV in the perinatal lamb, even when it is enhanced by NO synthase inhibition. (Pediatr Res 59: 131-136, 2006)
\end{abstract}

$\mathrm{E}^{\mathrm{T}}$ are powerful vasoactive mediators synthesized and released by the vascular endothelium (1). Plasma levels of circulating ET-1, the predominant isoform of ET, vary with age: in the fetus and newborn infants they are higher than in neonates and infants up to 3 months of age; they then become nearly constant and similar to adult levels (2-4). ET-1 plasma levels are also elevated in newborns and children suffering from diseases associated with pulmonary hypertension (PHT) and are correlated with the severity of the disease (5-7).

ET have opposite vascular effects mediated through different receptors. $\mathrm{ET}_{\mathrm{A}}$ receptors, located on vascular smooth muscle cells, mediate ET-1 vasoconstriction. $\mathrm{ET}_{\mathrm{B}}$ receptors

Received February 14, 2005; accepted June 15, 2005

Correspondence: Dominique Biarent, M.D., Pediatric Intensive Care Unit, Hôpital Universitaire des Enfants Reine Fabiola, 15 av JJ Crocq, 1020 Brussels, Belgium, e-mail: dominique.biarent@huderf.be

Supported by grant no. 3.4567.00 from the Fonds de la Recherche Scientifique Médicale (Belgium). Bosentan was a generous gift from Dr. Martine Clozel (Actelion, Allschwil, Switzerland)

DOI: 10.1203/01.pdr.0000191138.34387.e2 are found on vascular smooth muscle cells, where they mediate vasoconstriction, and also on endothelial cells, where their stimulation produces vasodilation, presumably through the endothelial synthesis of $\mathrm{NO}$ and prostacyclin $(8,9)$. Activation of the $\mathrm{ET}_{\mathrm{B}}$ receptor mediates pulmonary clearance of circulating ET-1 and reuptake of ET-1 by endothelial cells (8). In addition, although it is generally proposed that endothelial NO synthesis is related to ET-B receptor stimulation (8-11), another study shows that activation of ET-A receptors also can enhance NO production in the vasculature (12). In experimental studies on the regulation of the pulmonary vascular tone in perinatal lambs, it has also been demonstrated that ET-1 produces various hemodynamic effects (vasoconstriction as well vasodilation), depending on the presence of different types of ET-receptors with opposite effects (10,13-18). Thus, the role played by endogenous ET in the regulation of basal and increased vascular tone in perinatal experimental models remains uncertain.

ET have also been hypothesized to play a role in the mediation of HPV (19). Increased levels of ET-1 in the plasma and higher levels of ET-1 mRNA and $\mathrm{ET}_{\mathrm{A}}$ receptors in the lung, were measured in rats exposed to short- and long-term hypoxia $(20,21)$. Pretreatment with the $\mathrm{ET}_{\mathrm{A}}$ receptor antagonist BQ-123 curtails the increase in pulmonary vascular tone secondary to acute or chronic hypoxia in rats and lambs $(17,22,23)$. Using intact newborn lambs, Wong et al. (14) found ET-1 not to be involved in the regulation of HPV. These discrepancies in the possible role of ET regulating HPV might be explained, at least in part, by the variable release of NO, which has been shown to limit hypoxic pulmonary vascular tone in intact animals (24-28).

In the context of previous experiments from our laboratory studying the possible role of endothelial mediators on pulmonary vascular tone in an anesthetized (adult) dog model, these experiments were set up to investigate the effects of bosentan on pretreated lambs with L-NA at controlled flow (28).

\footnotetext{
Abbreviations: ET, endothelin; $\mathbf{F i o}_{2}$, inspired oxygen fraction; HPV, hypoxic pulmonary vasoconstriction L-NA, nitro-L-arginine; NO, nitric oxide; Ppa, pulmonary artery pressure; Ppao, occluded Ppa; Psa, systemic arterial pressure; PVR, pulmonary vascular resistance; $\mathbf{Q}$, cardiac output
} 
We started from the hypothesis demonstrated in the dog experiments, that the vasoconstrictive effects of ET are selflimited by an ET-induced synthesis of endogenous NO (28). For that purpose, we examined the effects of endogenous ET blockade on hyperoxic and hypoxic vascular tone, with and without NO synthase inhibition by L-NA in intact perinatal lambs. As ET have opposed vascular effects mediated by different receptors and $\mathrm{ET}_{\mathrm{A}}$ as well as $\mathrm{ET}_{\mathrm{B}}$ receptor stimulation enhances NO production, a complete blockade of endogenous ET requires both $\mathrm{ET}_{\mathrm{A}}$ and $\mathrm{ET}_{\mathrm{B}}$ receptor blockade (12).

The effects of hypoxia and drugs on pulmonary vascular tone were evaluated by constructing multipoint pressure/flow plots, which has been previously demonstrated in experiments from our laboratory to be the method of preference to evaluate the functional state of the pulmonary circulation $(24,28,29)$. This approach allows discrimination between active from passive changes of Ppa and PVR. To our knowledge, this method has never been reported in a model of intact perinatal lamb.

\section{METHODS}

Experiments were conducted in accordance with the Guide for the Care and Use of Laboratory Animals of the National Institutes of Health and were approved by the Committee on the Care and Use of Animals in Research of the School of Medicine of the Université Libre de Bruxelles.

Animal preparation. Twenty-one mixed-breed western lambs (age, 15-30 $\mathrm{d}$; weight, $5.7 \pm 2.4 \mathrm{~kg})$ were anesthetized with ketamine $(10 \mathrm{mg} / \mathrm{kg}$ i.v. $)$ through an over-the-needle catheter inserted percutaneously in a hind leg vein. Profound anesthesia was obtained by administering pentobarbital sodium (20 $\mathrm{mg} / \mathrm{kg}$ i.v.). The animals were paralyzed with pancuronium bromide $(0.2$ $\mathrm{mg} / \mathrm{kg}$ i.v.), intubated with a cuffed endotracheal tube (4.5-mm internal diameter), and ventilated (Elema 900 C, Siemens Elema, Sölna, Sweden) with a tidal volume of $10-12 \mathrm{~mL} / \mathrm{kg}$ adjusted to maintain carbon dioxide tension in arterial blood $\left(\mathrm{PaCO}_{2}\right)$ between 35 and $45 \mathrm{~mm} \mathrm{Hg}$, a positive end-expiratory pressure of $3 \mathrm{~cm} \mathrm{H}_{2} \mathrm{O}$, a sigh, a respiratory rate of 30 breaths/min, and an $\mathrm{FiO}_{2}$ of 0.4 during the preparation. This higher than normal $\mathrm{FiO}_{2}$ was selected to maintain the lungs above the threshold for HPV (28).

Continuous infusion of a sodium bicarbonate solution $(7 \%)$ was started at a rate of $1 \mathrm{mEq} / \mathrm{kg} / \mathrm{h}$ and was adjusted to maintain arterial $\mathrm{pH}$ above 7.30. Antibiotic prophylaxis (cefazoline $100 \mathrm{mg} / \mathrm{kg}$ ) was given at the beginning of the preparation and after $6 \mathrm{~h}$.

Pentobarbital (3 mg/kg i.v.) and pancuronium bromide $(0.1 \mathrm{mg} / \mathrm{kg})$ were given on a repeated hourly basis, to maintain anesthesia and paralysis. Central body temperature was kept in the normal range $\left(39-40^{\circ} \mathrm{C}\right)$ with an infrared rewarmer and a heating blanket throughout the preparation and the entire experiment.

A femoral artery (Ledercath $20 \mathrm{G}$ ) and a balloon-tipped, flow-directed pulmonary catheter (model 132-F5, Baxter Edwards, Irvine, CA) were respectively inserted after denudation of the right femoral artery and right external jugular vein. They allowed measurements of systemic and pulmonary hemodynamics and sampling of arterial and mixed venous blood and were positioned by means of pressure monitoring. A balloon-tipped catheter (model 132-F7, Baxter Edwards) was advanced into the inferior vena cava through a right femoral venotomy. Filling of the balloon with normal saline produced a titratable decrease in $\mathrm{Q}$ by reducing venous return. The distal port of the inferior vena caval catheter was used for fluid and drug administration. Thrombus formation along the catheters was prevented by heparin (100 IU/kg i.v.).

Glucose homeostasis was maintained by a continuous infusion of a glucose $10 \%$ in water solution (infusion rate, $2.5 \mathrm{~mL} / \mathrm{kg} / \mathrm{h}$ ). After preparation, the animal was allowed to stabilize for $1 \mathrm{~h}$.

Standard measurements. Heart rate (HR) was determined from a continuously monitored electrocardiographic lead.

Pulmonary and systemic arterial pressures (Psa) were measured using Gould Statham P50 transducers (Gould, Cleveland, OH). HR and vascular pressures were displayed on a monitor (Sirecust 404, Siemens, Erlangen, Germany) and recorded on a six-channel recorder (model 2600S, Gould). The pressure transducers were zero referenced at mid-chest and vascular pressures were recorded at end expiration. Q was measured by thermodilution using injections of $5 \mathrm{~mL}$ of $0.9 \%$ sodium chloride at $0^{\circ} \mathrm{C}$ and a computer (9520-A CO-set, Edwards Laboratories, Santa Ana, CA); it was calculated as the mean of at least three successive measurements.

Arterial and mixed venous blood gases were determined immediately after drawing the samples by a tonometered automated analyzer (ABL2, Radiometer, Copenhagen, Denmark) and corrected for temperature.

The pulmonary vascular pressure signals were sampled at $200 \mathrm{~Hz}$ using an analog/digital converter (DAS 8-PGA, Keithley-Metrabyte, Taunton, MA) and stored and analyzed on a personal computer.

Experimental protocol. In all lambs, a first four-point $\mathrm{Ppa}-\mathrm{Ppao} / \mathrm{Q}$ relationship was constructed at baseline $\left(\mathrm{FiO}_{2} \mathrm{0.4}\right)$. One point was generated with the vena caval balloon being empty (first point = high Q) and three points with stepwise filling of the balloon (last point = low Q). One such relationship was generated in about $30 \mathrm{~min}$. Arterial and mixed venous blood gases were measured at each point of the plot. The same procedure was repeated with an $\mathrm{FiO}_{2}$ 0.1. Each $\mathrm{FiO}_{2}$ was applied for at least 10 min to allow stabilization before new measurements were done. In a series of pilot experiments (data not shown) with solvent alone, we were able to reproduce identical hypoxic responses at least up to three times.

Two further hypoxic challenges were performed $30 \mathrm{~min}$ after the start of either an infusion of solvent (normal saline) followed by an infusion of bosentan (Actelion, Allschwill, Switzerland) given as an i.v. bolus of $5 \mathrm{mg} / \mathrm{kg}$ followed by a constant infusion of $5 \mathrm{mg} / \mathrm{kg}$ (Group 1: $n=7$ ); or an infusion of L-NA (Sigma-Aldrich, Bornem, Belgium) alone given as an i.v. bolus of 5 $\mathrm{mg} / \mathrm{kg}$ followed by a constant infusion of $5 \mathrm{mg} / \mathrm{kg}$ (Group 2: $n=7$ ); or an infusion of L-NA followed by an infusion of bosentan (Group 3: $n=7$ ). The infusion rates were adapted during the experiments so that at the end of all pressure/flow measurements all lambs received the same total amount of bosentan (i.e. $10 \mathrm{mg} / \mathrm{kg}$ ) and L-NA (i.e. $10 \mathrm{mg} / \mathrm{kg}$ ). The dosage of bosentan has been shown to provide optimal ET blockade in anesthetized dogs and sheep $(28,30)$. The dose of L-NA has been shown to block NO synthase in lambs (31) as well as in dogs (24). Lambs were randomly allocated to one of the three study groups. L-NA was dissolved in $25 \mathrm{~mL}$ of normal saline and bosentan was diluted in heated, distilled, sterile water just before the experiments.

Data analysis. All results are expressed as means \pm SEM. Q is expressed in $\mathrm{mL} / \mathrm{kg} / \mathrm{min}$. The individual (Ppa - Ppao)/Q plots were essentially linear. The correlation coefficients of all individual plots were $>0.8$ except in one plot that was deleted from analysis. A least squares regression analysis was used to obtain the slopes and the zero-flow pressure intercepts of the individual (Ppa - Ppao)/Q plots. Values of Ppa - Ppao interpolated from the regression analysis for individual lambs were averaged at $50 \mathrm{~mL} / \mathrm{kg} / \mathrm{min}$ intervals of Q from 100 to $200 \mathrm{~mL} / \mathrm{kg} / \mathrm{min}$ to obtain the composite (Ppa Ppao)/Q plots shown in the left panel of Figures 1-3. HPV was defined as the hypoxia-induced increase in the Ppa - Ppao gradient at identical $\mathrm{Q}$, i.e. low and high Q (Figs. 1-3, right panels). A two-factor ANOVA for multiple measurements was used to assess the effects of hypoxia and drugs on hemodynamics and blood gases. When the F-ratio of the ANOVA reached a value of $p<0.05$, modified $t$ tests were used to determine which means differed.

\section{RESULTS}

Results from the three study groups are presented in Tables 1-3 and Figures 1-3. At baseline, hemodynamic and blood gas values did not differ between study groups. Reduction of Q significantly decreased mean Psa, Ppa, Ppao, right atrial pressure, and mixed venous oxygen tension $\left(\mathrm{PvO}_{2}\right)$. Hypoxia significantly reduced the oxygen tension in arterial blood $\left(\mathrm{PaO}_{2}\right)$ and $\mathrm{PvO}_{2}$ and increased Ppa and Ppa-Ppao without changes in $\mathrm{Q}$, indicating pulmonary vasoconstriction.

Effects of solvent. Solvent had no significant effect on hemodynamics and blood gases and did not affect the (Ppa Ppao)/Q relationships during hyperoxia or hypoxia (Table 1, Fig. 1).

Effects of bosentan alone. Bosentan significantly decreased Ppa and Ppa - Ppao in hyperoxia as well as in hypoxia (Table 1, Fig. 1), so that HPV was not significantly affected (Fig. 1). Bosentan also decreased mean Psa at $\mathrm{FiO}_{2} 0.4$ and at $\mathrm{FiO}_{2} 0.1$ (Table 1). 
Table 1. Blood gas and hemodynamic data, solvent followed by bosentan (BOS) (group 1, $n=7$ )

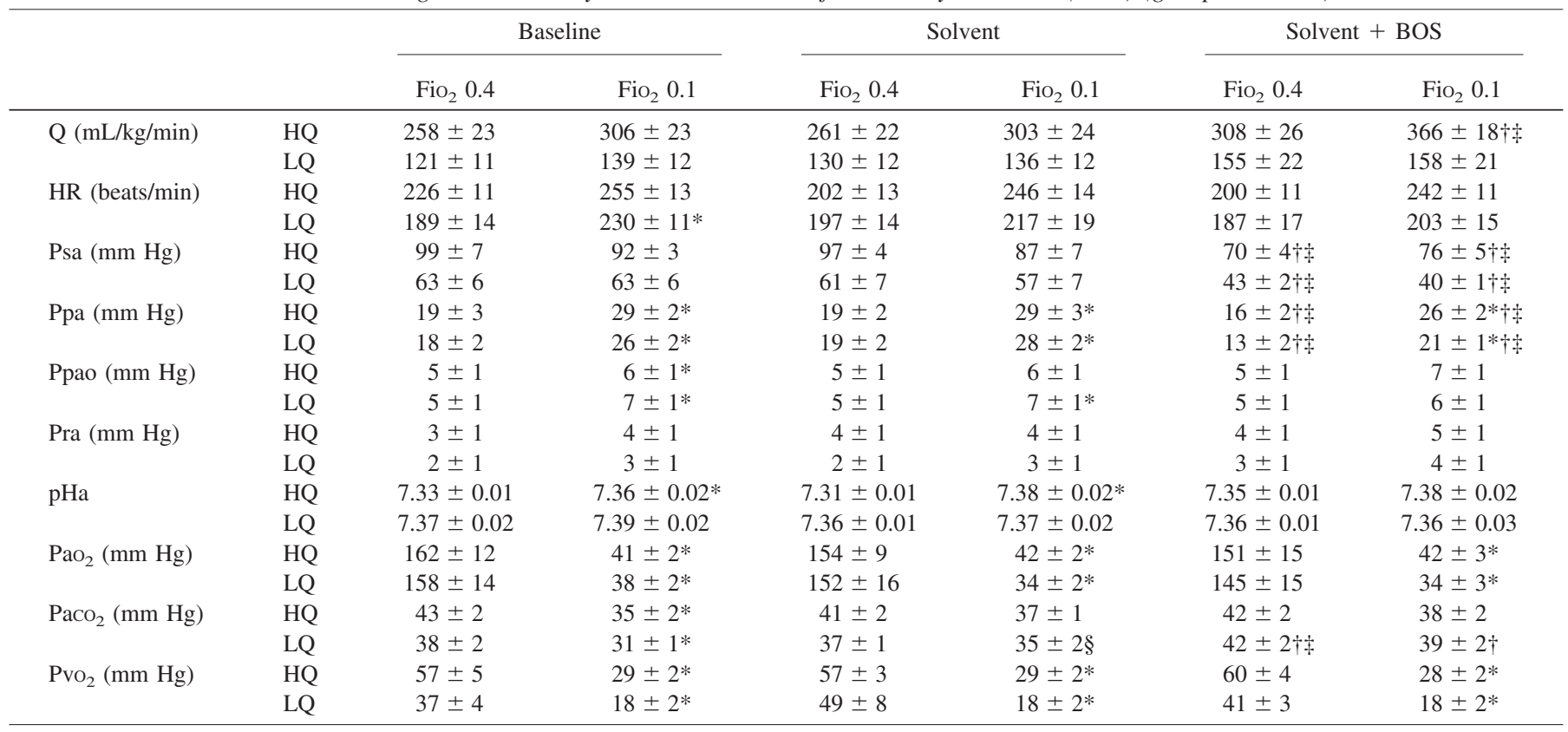

$\mathrm{HQ}$, highest $\mathrm{Q}$ of the pressure/flow plots; LQ, lowest Q of the pressure/flow plots; Pra, right atrial pressure; $\mathrm{pHa}$, arterial $\mathrm{pH}$. Data are presented as mean \pm SEM.

$* p<0.05$, compared with $\mathrm{FiO}_{2}$ 0.4, same drug condition.

$\dagger p<0.05$, bosentan compared with baseline, same $\mathrm{FiO}_{2}$.

$\ddagger p<0.05$, bosentan compared with solvent, same $\mathrm{Fio}_{2}$.

$\S p<0.05$, solvent compared with baseline, same $\mathrm{FiO}_{2}$.
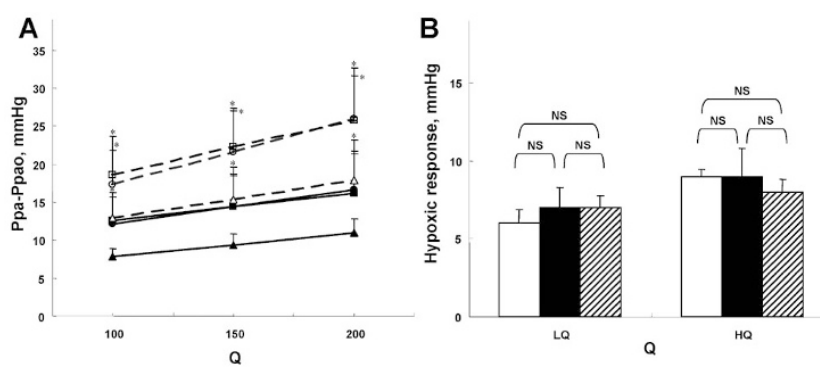

Figure 1. (A) Multipoint mean Ppa minus Ppao at standardized (100-200 $\mathrm{mL} / \mathrm{kg} / \mathrm{min}$ ) Q plots at baseline (circles), after the administration of solvent (squares) and after the administration of bosentan (triangles) in seven lambs during hyperoxia (solid symbols and lines) and hypoxia (open symbols and dashed lines). Vertical bars indicate the SEM; $n=7 .{ }^{*} p<0.005$ between hypoxia and hyperoxia for the same drug condition. $(B)$ Hypoxic response defined as the increase in the gradient between Ppa - Ppao measured at constant $\mathrm{Q}(\mathrm{LQ}=$ lowest $\mathrm{Q}$ of the pressure/flow plots; $\mathrm{HQ}=$ highest $\mathrm{Q}$ of the pressure/flow plots) in response to a reduction in the fraction of inspired oxygen from 0.4 to 0.1 at baseline (open bars), after administration of solvent (closed bars), and after administration of bosentan (shaded bars). Vertical bars indicate the SEM.

Effects of L-NA alone. L-NA increased Ppa and Ppa - Ppao in hyperoxia and, with a larger magnitude, in hypoxia (Table 2, Fig. 2), so that HPV was enhanced after L-NA (Fig. 2). L-NA also increased mean Psa (Table 2).

Effects of bosentan after L-NA. After L-NA, bosentan significantly decreased Ppa and Ppa - Ppao in hypoxia, but these pressure values remained higher than the baseline values, and HPV was not significantly affected (Table 3, Fig. 3). During hypoxia, L-NA shifted the (Ppa - Ppao)/Q relationship to higher pressures, and bosentan given after L-NA reduced
Ppa - Ppao at all levels of Q. As observed in the first study group, bosentan decreased mean Psa (Table 3).

\section{DISCUSSION}

In our model of anesthetized intact lamb, ET receptor antagonism by bosentan decreased pulmonary and systemic vascular tone both in hyperoxia and hypoxia. NO synthase inhibition increased pulmonary vascular tone more in hypoxia than in hyperoxia so that HPV was enhanced. After L-NA, bosentan still decreased pulmonary vascular tone in hypoxia but did not affect the magnitude of HPV. This suggests that the vasodilator effect of bosentan may be due to a non-NOdependent mechanism. Because a combined $\mathrm{ET}_{\mathrm{A}}$ and $\mathrm{ET}_{\mathrm{B}}$ receptor antagonist was used, the results from these experiments cannot identify the respective effects of these receptors on HPV.

The investigation of pulmonary hemodynamics in intact animals and humans usually rests on the determination of PVR (32). PVR is calculated as the difference between mean Ppa and Ppao, assumed to be equal to left atrial pressure, divided by $\mathrm{Q}$ (32). This method is based on the assumptions that the Ppa - Ppao/Q relationship is linear and passes through the origin. The latter is in fact incorrect when the lungs are diseased and/or hypoxic $(24,29)$. When the extrapolated pressure intercept of the pressure-flow plots, i.e. the closing pressure of the pulmonary vessels or their effective downstream pressure, exceeds Ppao, the calculation of PVR cannot discriminate between passive (flow-dependent) and active changes in pulmonary artery pressure. 
Table 2. Blood gas and hemodynamic data, L-NA alone (group 2, $n=7$ )

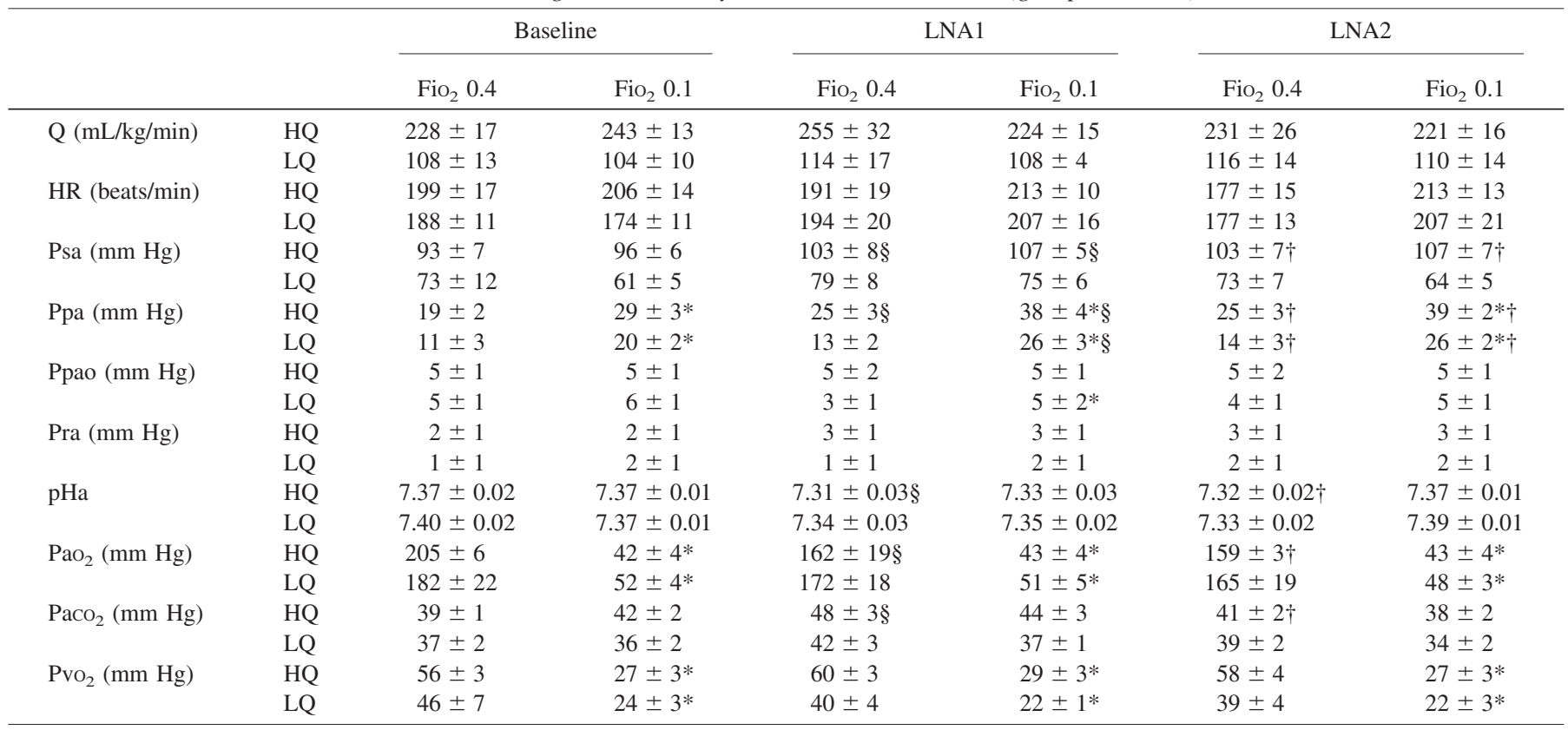

HQ, highest $\mathrm{Q}$ of the pressure/flow plots; LQ, lowest $\mathrm{Q}$ of the pressure/flow plots; Pra, right atrial pressure; $\mathrm{pHa}$, arterial $\mathrm{pH}$. Data are presented as mean \pm SEM. $* p<0.05$ compared with $\mathrm{FiO}_{2}$ 0.4, same drug condition.

$\dagger p<0.05$ L-NA2 compared with baseline, same $\mathrm{FiO}_{2}$.

$\S p<0.05$ L-NA1 compared with baseline, same $\mathrm{Fio}_{2}$.
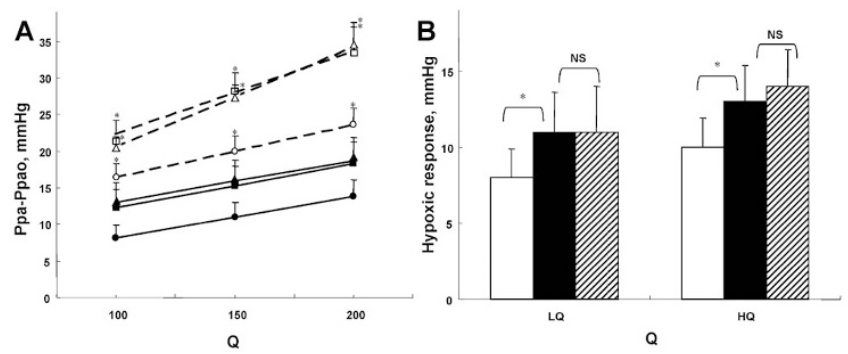

Figure 2. (A) Multipoint mean Ppa minus Ppao at standardized (100-200 $\mathrm{mL} / \mathrm{kg} / \mathrm{min}$ ) Q plots at baseline (circles), after the subsequent administration of two doses of L-NA [L-NA1 (squares) and L-NA2 (triangles)] in seven lambs during hyperoxia (solid symbols and lines) and hypoxia (open symbols and dashed lines). Vertical bars indicate the SEM; $n=7$. $* p<0.005$ between hypoxia and hyperoxia for the same drug condition. (B) Hypoxic response defined as the increase in the gradient between Ppa - Ppao measured at constant Q (LQ = lowest $\mathrm{Q}$ of the pressure/flow plots; HQ = highest $\mathrm{Q}$ of the pressure/flow plots) in response to a reduction in the $\mathrm{FiO}_{2}$ from 0.4 to 0.1 at baseline (open bars) and after subsequent administration of two doses of L-NA [LNA1 (closed bars) and L-NA2 (shaded bars)]. Vertical bars indicate the SEM. $* p<0.005$.

For that reason, it is preferable to evaluate the functional state of pulmonary circulation by multipoint pressure/flow plots, or to measure pulmonary vascular pressures at a constant flow. To our knowledge, this methodology has never been used to examine the pulmonary vascular response in the intact lamb model.

Bosentan is a nonpeptide mixed antagonist of ET-receptors, obtained by structural optimization of the less potent $\mathrm{ET}_{\mathrm{A}} / \mathrm{ET}_{\mathrm{B}}$ antagonist Ro 46-2005. Bosentan competitively antagonizes the specific binding of ET-1 on human smooth muscle cells (i.e. $\mathrm{ET}_{\mathrm{A}}$ receptors) and it has been demonstrated, in porcine trachea, that it also inhibits the binding of selective $\mathrm{ET}_{\mathrm{B}}$ ligands. Contractions induced by ET-1 in isolated rat aorta (via $\mathrm{ET}_{\mathrm{A}}$ receptor stimulation) and by the selective $\mathrm{ET}_{\mathrm{B}}$ agonist sarafotoxin $\mathrm{S} 6 \mathrm{C}$ in rat trachea, were competitively inhibited by bosentan. In vivo, bosentan inhibits the pressor response to big ET-1 both after intravenous and oral administration, and this with a long duration of action and no intrinsic agonist activity (33).

The simultaneous inhibition of $\mathrm{ET}_{\mathrm{A}}$ and $\mathrm{ET}_{\mathrm{B}}$ receptors shows that the net effect of ET in the intact anesthetized perinatal lamb results in pulmonary vasoconstriction. Coe $e t$ al. $(34,35)$ reported that specific $\mathrm{ET}_{\mathrm{A}}$ antagonists reversed the pulmonary hypertension when induced by hypoxia in conscious perinatal lambs, whereas, contrary to our findings, these compounds had no effect on pulmonary vascular tone in normoxia. Whether additional $\mathrm{ET}_{\mathrm{B}}$ blockade by bosentan is responsible for the pulmonary vasodilation in hyperoxia is speculative, but could suggest a pulmonary vasoconstrictor effect of $\mathrm{ET}_{\mathrm{B}}$ receptors in resting conditions. It was shown that ET-induced vascular contraction is mediated by $\mathrm{ET}_{\mathrm{A}}$ and $\mathrm{ET}_{\mathrm{B}}$ receptors located on vascular smooth muscle cells (36).

When endogenous NO production was inhibited by L-NA, the pulmonary vascular tone increased in hyperoxia and even more in hypoxia, which confirms the pulmonary vasodilating action of NO. In adult animals, we previously observed that L-NA increased HPV but did not affect hyperoxic Ppa (24). This study suggests that NO mediates resting pulmonary vascular tone in intact anesthetized newborn lambs and that NO is further released during hypoxia. Thus, it appears that pulmonary vascular tone in perinatal lambs is the result of the balanced influences of NO and ET. However, other vasoconstrictors such as serotonin, angiotensin II, prostaglandin D2, and vasodilators such as prostacyclin and endothelium- 
Table 3. Blood gas and hemodynamic data, L-NA followed by L-NA + bosentan (BOS) (group 3, $n=7$ )

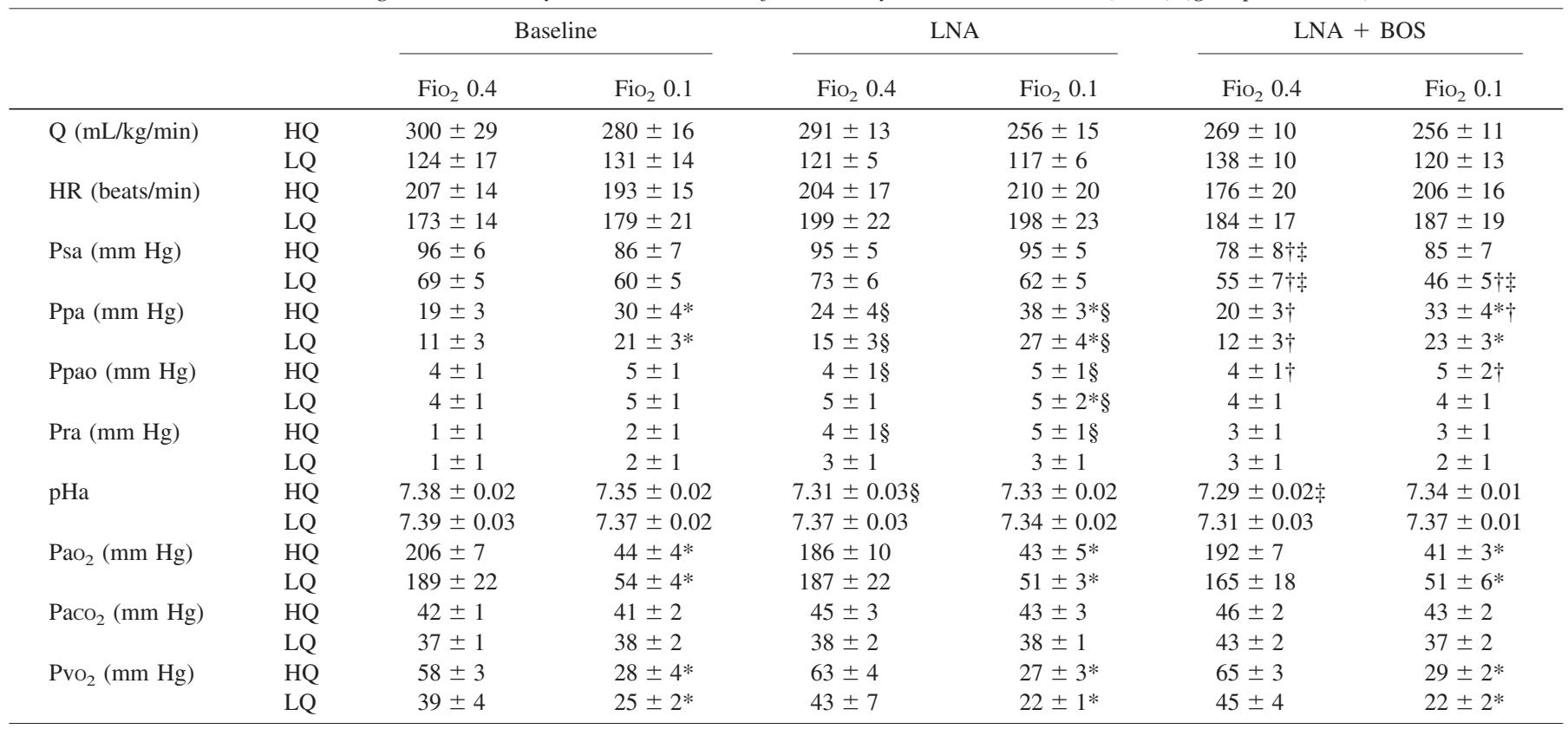

HQ, highest $\mathrm{Q}$ of the pressure/flow plots; LQ, lowest $\mathrm{Q}$ of the pressure/flow plots; Pra, right atrial pressure; $\mathrm{pHa}$, arterial pH. Data are presented as mean \pm SEM.

$* p<0.05$ compared with $\mathrm{Fio}_{2}$, same drug condition.

$\dagger p<0.05 \mathrm{~L}-\mathrm{NA}+$ bosentan compared with baseline, same $\mathrm{FiO}_{2}$.

$\ddagger p<0.05 \mathrm{~L}-\mathrm{NA}+$ bosentan compared with $\mathrm{L}-\mathrm{NA}$, same $\mathrm{FiO}_{2}$.

$\S p<0.05$ L-NA compared with baseline, same $\mathrm{FiO}_{2}$.
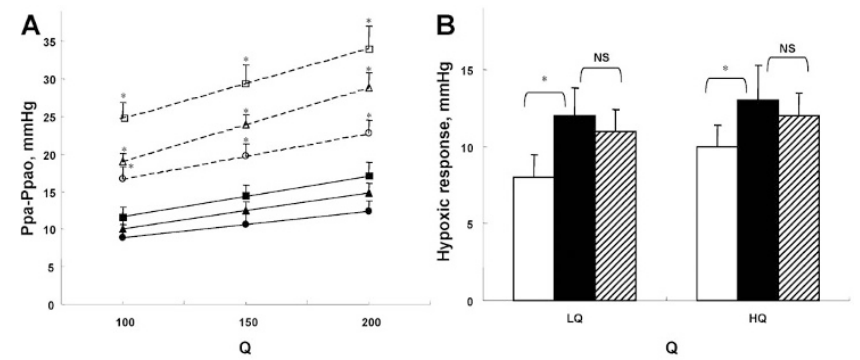

Figure 3. (A) Multipoint mean pulmonary artery pressure (Ppa) minus occluded Ppa (Ppao) at standardized (100-200 mL/kg/min ) Q plots at baseline, after the administration of L-NA followed by the administration of bosentan in seven lambs during hyperoxia (solid symbols and lines) and hypoxia (open symbols and dashed lines). Vertical bars indicate the SEM; $n=7 . * p<0.005$ between hypoxia and hyperoxia for the same drug condition. $(B)$ Hypoxic response defined as the increase in the gradient between Ppa-Ppao measured at constant $\mathrm{Q}(\mathrm{LQ}=$ lowest $\mathrm{Q}$ of the pressure/flow plots; HQ = highest $\mathrm{Q}$ of the pressure/flow plots) in response to a reduction in the $\mathrm{FiO}_{2}$ from 0.4 to 0.1 at baseline (open bars), after administration of L-NA (closed bars) followed by the administration of bosentan (shaded bars). Vertical bars indicate the SEM. ${ }^{*} p<0.005$.

derived hyperpolarizing factor may also play a role in regulating pulmonary vascular tone (37).

Bosentan did not reverse the L-NA-induced pulmonary hypertension, although it still reduced Ppa during hypoxia when given after L-NA. Perhaps a higher dosage of bosentan would be necessary.

Coe et al. (34) reported that selective $\mathrm{ET}_{\mathrm{A}}$ antagonists reversed pulmonary hypertension when induced by hypoxia, but not when elicited by an infusion of a thromboxane A2 analog. These observations suggest that ET antagonists could selectively reduce pulmonary hypertension if due to hypoxia, but not if due to other stimuli.
HPV is associated with the release of ET-1, suggesting a role for ET-1 in HPV $(19,20)$. However, in several studies, the role of ET in HPV could not be demonstrated after administration of selective or non selective ET antagonists $(14,16,28,29,38-40)$.

Our results are in agreement with the idea that ET do not play a major role in HPV in the perinatal lamb, even when it is enhanced by NO synthase inhibition.

The present study suggests that ET are involved in the control of pulmonary vascular tone in hyperoxia and hypoxia, and that their effects are not limited to a NO-dependent mechanism. This conclusion is limited to the acute setting of anesthetized lambs. However, we would like to stress on the use of an adequate methodology, i.e. multipoint pressure-flow relationships, in evaluating the functional status of the pulmonary circulation, which, without any doubt, adds to the scientific weight of our findings.

Acknowledgments. The authors thank Marie-Thérèse Gautier for her expert technical assistance.

\section{REFERENCES}

1. Yanagisawa M, Masaki T 1989 Endothelin, a novel endothelium-derived peptide. Pharmacological activities, regulation and possible roles in cardiovascular control. Biochem Pharmacol 38:1877-1883

2. Yoshibayashi M, Nishioka K, Nakao K, Saito Y, Temma S, Matsumura M, Ueda T, Shirakami G, Imura H, Mikawa H 1991 Plasma endothelin levels in healthy children: high values in early infancy. J Cardiovasc Pharmacol 17:S404-S405

3. Ekblad H, Arjamaa O, Vuolteenaho O, Kaapa P, Kero P 1993 Plasma endothelin-1 concentrations at different ages during infancy and childhood. Acta Paediatr 82:302_ 303

4. Haegerstrand A, Hemsen A, Gillis C, Larsson O, Lundberg J 1989 Endothelin: presence in umbilical vessels, high level in fetal blood and potent vasoconstrictor effect. Acta Physiol Scand 137:541-542 
5. Allen SW, Chatfield BA, Koppenhafer SA, Schaffer MS, Wolfe RR, Abman SH 1993 Circulating immunoreactive endothelin-1 in children with pulmonary hypertension. Association with acute hypoxic pulmonary vasoreactivity. Am Rev Respir Dis 148:519-522

6. Yoshibayashi M, Nishioka K, Nakao K, Saito Y, Matsumura M, Ueda T, Temma S, Shirakami G, Imura H, Mikawa H 1991 Plasma endothelin concentrations in patients with pulmonary hypertension associated with congenital heart defects. Circulation $84: 2280-2285$

7. Widlitz A, Barst RJ 2003 Pulmonary arterial hypertension in children. Eur Respir J 21:155-176

8. Michael JR, Markewitz BA 1996 Endothelins and the lung. Am J Respir Crit Care Med 154:555-581

9. Shetty SS, Okada T, Webb RL, DelGrande D, Lappe RW 1993 Functionally distinct endothelin B receptors in vascular endothelium and smooth muscle. Biochem Biophys Res Commun 191:459-464

10. Sato K, Morio Y, Morris KG, Rodman DM, McMurtry IF 2000 Mechanism of hypoxic pulmonary vasoconstriction involves ET(A) receptor-mediated inhibition of K(ATP) channel. Am J Physiol Lung Cell Mol Physiol 278:L434-L442

11. Ivy D, McMurtry IF, Yanagisawa M, Gariepy CE, Le Cras TD, Gebb SA, Morris KG, Wiseman RC, Abman SH 2001 Endothelin B receptor deficiency potentiates ET-1 and hypoxic pulmonary vasoconstriction. Am J Physiol Lung Mol Physiol 280:L1040-1048

12. Fujii Y, Magder S, Cernacek P, Goldberg P, Guo Y, Hussain SN 2000 Endothelin receptor blockade attenuates lipopolysaccharide-induced pulmonary nitric oxide production. Am J Respir Crit Care Med 161:982-989

13. Wong J, Fineman JR, Heymann MA 1994 The role of endothelin and endothelin receptors subtypes in the regulation of fetal pulmonary vascular tone. Pediatr Res 35:664-670

14. Wong J, Vanderford PA, Winters JW, Chang R, Soifer SJ, Fineman JR 1993 Endothelin-1 does not mediate acute hypoxic pulmonary vasoconstriction in the intact newborn lamb. J Cardiovasc Pharmacol 22:S262-S266

15. Wong J, Vanderford PA, Fineman JR, Chang R, Soifer SJ 1993 Endothelin-1 produces pulmonary vasodilation in the intact newborn lamb. Am J Physiol 265:H1318-H1325

16. Wong J, Vanderford PA, Winters J, Soifer SJ, Fineman JR 1995 Endothelinb receptor agonists produce pulmonary vasodilation in intact newborn lambs with pulmonary hypertension. J Cardiovasc Pharmacol 25:207-215

17. Wang Y, Coe Y, Toyoda O, Coceani F 1995 Involvement of endothelin-1 in hypoxic pulmonary vasoconstriction in the lamb. J Physiol 482:421-434

18. Black SM, Bekker JM, Johengen MJ, Parry AJ, Soifer SJ, Fineman JR 2000 Altered regulation of the ET-1 cascade in lambs with increased pulmonary blood flow and pulmonary hypertension. Pediatr Res 47:97-106

19. Kourembanas S, Marsden PA, McQuillan LP, Faller DV 1991 Hypoxia induces endothelin gene expression and secretion in cultured human endothelium. J Clin Invest 88:1054-1057

20. Shirakami G, Nakao K, Saito Y, Magaribuchi T, Jougasaki M, Mukoyama M, Arai H, Hosoda K, Suga S, Ogawa Y, et al 1991 Acute pulmonary alveolar hypoxia increases lung and plasma endothelin-1 levels in conscious rats. Life Sci 48:969-976

21. Elton TS, Oparil S, Taylor GR, Hicks PH, Yang RH, Jin H, Chen YF 1992 Normobaric hypoxia stimulates endothelin-1 gene expression in the rat. Am J Physiol 263:1260-1264
22. Oparil S, Chen SJ, Meng QC, Elton TS, Yano M, Chen YF 1995 Endothelin-A receptor antagonist prevents acute hypoxia-induced pulmonary hypertension in the rat. Am J Physiol 268:L95-L100

23. Bonvallet ST, Zamora MR, Hasunuma K, Sato K, Hanasato N, Anderson D, Stelzner TJ 1994 BQ123, an ETA-receptor antagonist, attenuates hypoxic pulmonary hypertension in rats. Am J Physiol 266:H1327-H1331

24. Leeman M, de Beyl VZ, Biarent D, Maggiorini M, Mélot C, Naeije R 1999 Inhibition of cyclooxygenase and nitric oxide synthase in hypoxic vasoconstriction and oleic acid-induced lung injury. Am J Respir Crit Care Med 159:1383-1390

25. Fineman JR, Heymann MA, Soifer SJ 1991 N omega-nitro-L-arginine attenuates endothelium-dependent pulmonary vasodilation in lambs. Am J Physiol 260:H1299H1306

26. Gordon JB, Tod ML 1993 Effects of N omega-nitro-L-arginine on total and segmental vascular resistances in developing lamb lungs. J Appl Physiol 75:76-85

27. Tod ML, Cassin S 1992 Endothelin-1-induced pulmonary arterial dilation is reduced by N omega-nitro-L-arginine in fetal lambs. J Appl Physiol 72:1730-1734

28. Hubloue I, Biarent D, Abdel Kafi S, Bejjani G, Kerbaul F, Naeije R, Leeman M 2003 Endogenous endothelins and nitric oxide in hypoxic pulmonary vasoconstriction. Eur Respir J 21:19-24

29. Hubloue I, Biarent D, Abdel Kafi S, Bejjani G, Mélot C, Naeije R, Leeman M 2003 Endothelin receptor blockade in canine oleic acid-induced lung injury. Intensive Care Med 29:1003-1006

30. Fischer SR, Traber DL 1999 L-Arginine and endothelin receptor antagonist bosentan counteract hemodynamic effects of modified hemoglobin. Shock 11:283-290

31. Cornfield DN, Chatfield BA, McQueston JA, McMurtry IF, Abman SH 1992 Effects of birth-related stimuli on L-arginine-dependent pulmonary vasodilation in ovine fetus. Am J Physiol 262:H1474-H1481

32. Mitzner W 1983 Resistance of the pulmonary circulation. Clin Chest Med 4:127-137

33. Clozel M, Breu V, Gray GA, Kalina B, Löffler BM, Burri K, Cassal JM, Hirth G, Müller M, Neidhart W, et al 1994 Pharmacological characterization of bosentan, a new potent orally active nonpeptide endothelin receptor antagonist. J Pharmacol Exp Ther 270:228-235

34. Coe Y, Haleen SJ, Welch KM, Liu YA, Coceani F 2002 The endothelin A receptor antogonists PD 156707 (CI-1020) and PD 180988 (CI-1034) reverse the hypoxic pulmonary vasoconstriction in the perinatal lamb. J Pharmacol Exp Ther 302:672-680

35. Coe Y, Haleen SJ, Welch KM, Coceani F 2000 The endothelin-A-receptor antagonist PD 180988 (CI-1034) selectively reverses the pulmonary vasoconstrictor response to hypoxia in lamb. J Cardiovasc Pharmacol 36:S331-S333

36. Galie N, Manes A, Branzi A 2004 The endothelin system in pulmonary arterial hypertension. Cardiovasc Res 61:227-237

37. Barnes PJ, Liu SF 1995 Regulation of pulmonary vascular tone. Pharmacol Rev 47:87-131

38. Lazor R, Feihl F, Waeber B, Kucera P, Perret C 1996 Endothelin-1 does not mediate the endothelium-dependent hypoxic contractions of small pulmonary arteries in rats. Chest 110:189-197

39. Takeoka M, Ishizaki T, Sakai A, Chang SW, Shigemori K, Higashi T, Ueda G 1995 Effect of BQ123 on vasoconstriction as a result of either hypoxia or endothelin-1 in perfused rat lungs. Acta Physiol Scand 155:53-60

40. Douglas SA, Vickery-Clark LM, Ohlstein EH 1993 Endothelin-1 does not mediate hypoxic vasoconstriction in canine isolated blood vessels: effect of BQ-123. Br J Pharmacol 108:418-421 